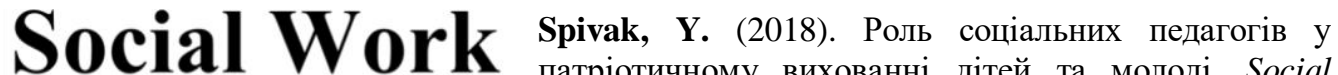
патріотичному вихованні дітей та молоді, Social \& Education Work and Education, Vol.

๑) SW\&E, 2018

\title{
РОЛЬ СОЦІАЛЬНИХ ПЕДАГОГІВ У ПАТРІОТИЧНОМУ ВИХОВАННІ ДІТЕЙ ТА МОЛОДІ
}

Yaroslav Spivak,

Ph.D., Associate professor,

Doctoral Student of the State Higher

Educational Institution

«Donbas State Pedagogical

University»

Str. G. Batyuka, 19, 84116, Donetsk

region,

Slavyansk, Ukraine,

Yaroslavspivak777@gmail.com

ORCID: 0000-0001-8829-2236

\section{Ярослав Співак,}

кандидат педагогічних

доиент,

докторант державного вищого навчального закладу

"Донбаський

державний

педагогічний університет»

м. Слов'янськ, Украӥна,

УДК 37:364.4

DOI: $10.25128 / 2520-6230.18 .4 .7$

Article history:

Received: October 12, 2018

1st Revision: November 20, 2018

Accepted: December 30, 2018
АНОТАЦІЯ. У статті зазначена актуальність проблеми патріотичного виховання дітей та молоді, формування у них національної свідомості та громадянської позииіі. Висвітлюється особлива роль патріотичного виховання в становленні молодої людини як громадянина своєї Батьківщини. Розглянуто патріотичне виховання у контексті сучасних сочіально-педагогічних реалій. Висвітлено кризову ситуачіюо сочіально-політичних умов існування молодого покоління. У сучасних умовах зазначено зростаючу роль соиіальних педагогів у патріотичному вихованні дітей та молоді. Означено основні завдання соиіальної роботи у даному напрямі, вимоги до професійних якостей сочіальних педагогів. Охарактеризовано основні технології соиіальної роботи, щчо можуть бути застосовані у формуванні патріотизму дітей $і$ молоді. Розкрито зміст наук, технологій соиіальної роботи з сім'ями, що постраждали від військової агресії. У статті соиіальну роботу розглянуто як вагомий засіб формування патріотизму дітей, молодих людей та їх сімей. Обгрунтована доиільність розробки оптимальних напрямів сочіально-педагогічної діяльності у патріотичному вихованні дітей та молоді Украӥни. Надано рекомендації соиіальним педагогам щчодо організачиї патріотичного виховання учнівської молоді в умовах освітніх закладів. Зроблено висновки щуодо важливої функиї сочіального педагога у співпраиі з усіма учасниками процесу патріотичного виховання молодого покоління. Наголошено на необхідності державної підтримки у иьому напрямку не тільки освітніх закладів, сочіальних установ, медичних, правових установ, громадських організаиій, а й обов'язково всіх охочих до цього прочесу. Запропоновані напрями подальших досліджень щиодо багатопланової діяльності соиіальних педагогів з формування нового покоління юних патріотів держави, сповнених бажсання відстоювати $i$ надалі незалежнність та процвітання Украӥни.

Ключові слова: патріотичне виховання дітей та молоді; патріотизм; роль соціального педагога; сочіальна робота; технології соиіальної роботи. 


\section{Вступ}

Сьогодні проблема захисту дітей та молоді в рамках державної молодіжної політики України є дуже великою. 3 кожним роком зростає показник соціальної незахищеності молодого покоління, обумовленого високим рівнем бідності та іншими факторами, що призводить до погіршення рівня життя, мінімізації можливостей розвитку молоді, іiі самореалізації в нашій країні. Враховуючи суспільно-політичну ситуацію, що склалася в Україні, однією з найскладніших та найгостріших проблем $\epsilon$ виховання у підростаючого покоління суспільних цінностей, моральних та патріотичних орієнтирів.

Дослідження проблем соціально-педагогічної діяльності 3 патріотичного виховання дітей та молоді України спирається на значний науково-практичний досвід соціальних педагогів. Колом наукових інтересів вітчизняних соціальних педагогів $\epsilon$ ідеї гармонізації взаємодії особистості і соціального середовища. Актуальною соціально-педагогічною проблемою в сучасних умовах залишається вирішення індивідуальних проблем соціалізації молоді, вивчення особистості молодої людини та довкілля, складання індивідуальної програми допомоги, що допоможе молодим людям зорієнтуватися у вирі суспільних подій і явищ, а також самостійному пошукові свого життєвого шляху, розвитку і самореалізації.

Докорінна реформа системи освіти, регулювання молодіжної зайнятості, забезпечення спеціальних економічних й юридичних гарантій, виконання стратегії національно-патріотичного виховання дітей та молоді $\epsilon$ пріоритетним завданням державної молодіжної політики України сьогодні вцілому, соціально-педагогічної науки та практики зокрема.

У наукових роботах І. Беха, К. Чорної (Бех \& Чорна, 2014), І. Ковальчука (Ковальчук, 2016), інших вітчизняних учених висвітлюється проблематика громадянської самосвідомості, формування ціннісних оріснтирів, патріотичного виховання дітей та молоді. Технології соціальної роботи соціальних педагогів розкрито у наукових працях Р. Вайноли (Вайнола, 2012 р.), Н. Заверико (Заверико, 2012 р.), А. Капської (Капська, 2015) та ін. Багато наукових доробок присвячено специфіці й особливостям соціально-виховного процесу у суспільстві. Однак, не означено роль соціальних педагогів у патріотичному вихованні дітей та молоді, застосування технологій їх соціальної роботи у цьому процесі.

Метою статті - визначити роль соціальних педагогів у патріотичному вихованні дітей та молоді.

Завдання дослідження: висвітлення соціально-політичних кризових умов існування молодого покоління; обгрунтування необхідності соціальної роботи 3 патріотичного виховання дітей та молоді; розкриття змісту технологій соціальної роботи соціальних педагогів 3 молодим поколінням у напрямі їх патріотичного виховання; надання рекомендацій соціальним педагогам з патріотичного виховання дітей та молоді.

Методологія дослідження: теоретичні (загальнотеоретичні принципи наукового пізнання, аналіз вітчизняної наукової літератури 3 досліджуваної проблеми); емпіричні (порівняльний аналіз і узагальнення). 


\section{Основна частина}

Сучасний історичний період, коли молода Українська державність витримує тяжке випробування на незалежність під час російської військової агресії на сході країни, поглиблення патріотичного виховання молоді має бути одним з основних стратегічних напрямків розбудови майбутнього суспільства. Патріотична складова в державній ідентифікації молоді ускладнюється критичним станом розколу політичних поглядів старших поколінь, що негативно впливає на виховання ними молоді, кризовим економічним станом, конфліктною ситуацією в суспільстві з питань мови та релігії. Збільшує проблему тотальна зневіра дорослого населення до влади країни, тому молодь самостійно не може визначити орієнтири та розуміння підстав для поваги до Української держави. Для нівелювання патріотичної ідентифікації підростаючого покоління, кремлівські організатори гібридної війни в Україні через підконтрольні їм засоби масової інформації постійно маніпулюють родинними зв'язками українського і російського народів, пов'язаними 3 цим культурними спадщинами. Любов до Батьківщини у дорослого населення i молоді стримує своїми обурливими корупційними діями українська влада. Тому для побудови кращого майбутнього України патріотичне виховання молоді стає ключовим питанням, яке покликано здійснювати просвітницьку роботу серед молоді для формування у неї свідомості про національні відмінності від інших країн, сприяє формуванню активній громадянській позиції, щоб суспільство змінювалося на краще. Тільки поступовим шляхом, реформами і державною підтримкою програм патріотичного виховання дітей та молоді, соціальним педагогам буде вдаватися прищеплювати повагу їм до своєї країни (Бех \& Чорна, 2014).

Соціальне середовище, в якому перебуває молода людина, має рішучій вплив на виховання особистості, тому соціальному педагогу необхідно враховувати особливості соціалізації в кожному окремому випадку. Взагалі, почуття патріотизму, в першу чергу має соціально-моральне походження, а не залежить від територіального розташування. Громадянська позиція молоді має формуватись під впливом національної самосвідомості і визнання пріоритету прав людини, тобто правової культури особистості. Надати імпульс для духовного оздоровлення нації покликане саме патріотичне виховання та професійна діяльність в цьому напрямку соціальних педагогів, яким відведена ключова роль в реалізації цілісної системи виховання патріотизму у молоді, формуванні у них активної життєвої позиції, змінювати свідомість молодих людей долучатися до справ, які можуть зробити нашу країну незалежною, демократичною, суверенною, правовою і соціальною державою. Саме дієвість і корисні для суспільства вчинки - головні, визначальні риси патріотизму. Формування патріотичної свідомості особистості - це еволюційний процес, який складається із багатьох етапів розвитку суспільства, національної єдності. Тому перед соціальними педагогами стоїть завдання реформувати освіту в аспекті патріотичного виховання дітей та молоді. Таких змін вимагають події революції Гідності (2013-2014 pp.), війна на сході України (з 2014 р. і до цього часу), під час яких загинула і далі гине велика кількість патріотів та цивільного населення, де діти втрачають своїх батьків, по всій країні ховають загиблих на війні рідних людей, звідки зростає соціальнополітична криза в суспільстві й ін. 
В такому вкрай напруженому соціальному середовищі соціальним педагогам необхідно бути готовим до самих складних питань соціальної роботи 3 дітьми та молоддю, у багатьох з яких батьки, родичі пройшли мобілізацію або знаходяться в зоні бойових дій, поранені, загиблі. Молодь завжди чекає конкретні компетентні відповіді на свої питання, які вкрай важливо надавати в максимально доступному форматі. Перед соціальними педагогами постає складне завдання сформувати у молоді розуміння національної гідності, розуміння необхідності суспільної єдності в умовах зовнішньої агресії для відновлення порядку та миру в Україні. Головне в такому процесі утримуватися від особистих політичних вподобань, не ставити перед дітьми нездійснених в найближчому часі обіцянок і давати зрозумілі роз'яснення процесів, які спрямовані на підрив національної єдності та національної безпеки в державі. В цих складних умовах соціальним педагогам необхідно постійно знаходити позитивні приклади дій громадянського суспільства для забезпечення незалежності країни, зміцнення іiі обороноздатності та економічного відродження.

Соціальні педагоги повинні бути спокійними та виваженими, створювати психологічно комфортну атмосферу безпеки у роботі з дітьми та молоддю, формувати у них адекватне відношення до подій, пов'язаних 3 війною. Відтак, особливої значущості набувають такі якості соціального педагога, як емпатія, співчуття, відданість, соціально-комунікативна культура.

Соціальні педагоги у патріотичному вихованні дітей і молоді застосовують наступні соціальні технології: профілактика, діагностика, консультування, адаптація, терапія, реабілітація, контроль. Першочерговим завданням відповідних фахівців у цьому напрямі $\epsilon$ профілактика або попередження негативних явищ у соціальному середовищі. Застосовуючи технології первинної профілактики соціальні педагоги мають проводити просвітницьку діяльність 3 дітьми та молоддю щодо кризової ситуації в країні, навчати адекватному реагуванні на події, соціально безпечної поведінки тощо (Ковальчук, 2016, с. 114).

Робота соціального педагога, як правило, починається із соціальної діагностики - дослідженні та виявленні причинно-наслідкових зв'язків подолання апатії дитини чи молодої людини патріотичного характеру, відслідковуючи динаміку виявленого рівня у них адаптації і патріотизму саме у кризові періоди. Отримані результати діагностики дозволяють соціальному педагогові підібрати методики, інструменти соціальної роботи 3 дітьми та молоддю щодо їх адаптації до соціально-політичних кризових ситуацій нашої країни.

Особливо важливим в сучасних умовах соціальної роботи $є$ використання технології соціального консультування. Проведення соціальними педагогами бесід та консультацій, зустрічей дітей, батьків та педагогів, представників національнопатріотичних громад 3 керівниками влади $\epsilon$ заходами вкрай важливими для збереження населення та розвитку нашої держави. Тематика консультування має бути направлена на виховання дітей та молоді 3 питань соціального забезпечення наших воїнів, тих хто знаходяться в зоні бойових дій, їх сімей. Соціальним педагогам необхідно бути готовими до діалогу різного формату з молоддю, яка потребує соціальної допомоги, взаємодіяти 3 громадськими організаціями, вчителями, батьками, що допоможе їм відновити і закріпити відчуття захищеності, безпеки. Суспільна солідарність у патріотичному вихованні дітей та молоді передбачає 
визначення особливостей взаємодії всіх учасників виховного процесу, організаційнометодичних засад партнерства та ін. Пріоритетом патріотичного виховання молоді $€$ орієнтація на усвідомлення молоддю, що вся сила в єдності нації. Соціальні педагоги мають реалізовувати проекти виховання у молоді патріотичного обов'язку, поваги до засад демократичної, правової держави, а також готовності до захисту своєї країни.

Необхідно враховувати і те, що по всієї території України живуть та навчаються діти $з$ окупованих територій. Багато сімей переселенців живуть у нетипових умовах свого існування, що змушує їх пристосовуватися до теперішнього середовища. Тому соціальні педагоги застосовують дієві технології соціальної адаптації і підтримки дітей та молоді у процесі їх соціалізації, пристосуванні до нових соціальних умов.

Патріотизм передбачає занурення у теоретичні витоки проблеми патріотичного виховання. Терапевтична робота соціального педагога $є$ більш ефективною завдяки спільній роботі з викладачами, педагогічним колективом, психологами, батьками, адміністрацією освітніх закладів, фахівцями соціальних служб, медичних, правових установ, громадських організацій, тощо. Така співпраця дозволить соціальному педагогові здійснювати інтегрований підхід щодо соціально-педагогічного супроводу дітей та молоді в сучасних умовах (Капська, 2015). Соціальна терапія та корекція стосунків у родинах переселенців, хто втратив рідних, постраждали від війни та ін., необхідно проводити не тільки в груповій формі, але і в індивідуальному форматі 3 кожною окремою особистістю. Головною метою такої соціальної терапії та корекції повинна бути повна адаптація до змінених умов життя. Технології соціальної терапії та корекції мають містити в собі ряд необхідних складових:

- розвиток громадянського мислення та гідності;

- формування високодуховної особистості;

- становлення патріотичних переконань громадянина незалежної держави;

- стимулювання до творчої індивідуальності, широкого світогляду, постійного самовдосконалення, самоосвіти та розвитку;

- усвідомлення того що патріотичне ставлення до суспільства і держави виявляється не тільки в героїчних діях, а більше в буденних та самовідданих справах.

Особлива увага повинна приділятися психологічно-соціальній реабілітації дітям загиблих, поранених, або військових, які були задіяні безпосередньо в зоні бойових дій. Результатом діяльності соціальних працівників з цією категорією громадян має бути психологічна допомога для створення в оточуючому іiі соціумі максимального соціального комфорту. Інструментом соціальної терапії для досягнення соціального комфорту може бути психологічна допомога в налагодженні соціальних відносин особистості, корегування iї дій. Для естетичного розвитку дітей та молоді корисним буде застосування різноманітних допоміжних засобів та варіантів соціальної терапії, таких як спортивна, художня, музична, загально мистецька та ін.

Виявляти проблеми соціальної адаптації дітей в таких родинах призначений соціальний контроль від соціальних служб населення, шкіл, інших навчальних та лікувальних закладів. Регулювання життєдіяльності молодого покоління в умовах кризи, збалансування їх взаємовідносин з державними установами, особливо в питаннях матеріального забезпечення та лікування $\epsilon$ важливими завданнями соціальних педагогів. (Ковальчук, 2016, с. 115). Для ефективного виконання 
поставлених завдань, соціальним працівникам необхідно постійно проводити моніторинг соціальних настроїв дорослого та підростаючого поколінь.

Співпраця соціальних педагогів 3 патріотичними громадськими, волонтерськими організаціями і православними релігійними громадами дозволить значно розширити спектр умов патріотичного виховання молоді. Прищеплення моральних і духовних засад молоді повинно відбуватися в унісон 3 сучасним історичним моментом щодо розбудови автокефальної православної церкви України, про що мріяло декілька поколінь українських патріотів. Застосування глибокого освітлення героїко-патріотичних здобутків всіх поколінь України, та іiі славних представників має стимулювати у молоді відчуття поваги і любові до історичного минулого й сучасного країни. Формуванню почуття гордості за Батьківщину можуть сприяти військово-патріотичні клуби, дитячі та молодіжні центри мистецтв, позашкільні спортивні секції та гуртки, в яких патріотичне виховання учнівської молоді повинно відбуватися на прикладах і досягненнях українських діячів культури, науки та спорту.

Формування у молоді ентузіазму до розбудови правової, економічнорозвинутої, демократичної та незалежної держави - кінцева мета роботи соціальних працівників. Це можливо досягнути тільки завдяки високоморальним і духовним засадам формування національної ідентичності та патріотичних цінностей, поваги та любові до своєї родини, рідної держави, народу, землі. Вкрай необхідно прищеплювати молоді сучасні норми толерантності до історичної спадшини всіх регіонів України, культур і народів інших держав. Тому патріотичний виховний процес в роботі соціальних педагогів 3 дітьми та молоддю необхідно відбудовувати на високодуховному рівні, вкладаючи в ідеї патріотизму чіткі особисті уявлення i переконання.

\section{Висновки}

Висновком викладеного матеріалу статті є впевненість у критичній необхідності поглиблення та розширення діяльності соціальних педагогів в процесі патріотичного виховання молоді, як ключового фактору в справі відбудови кращого майбутнього народу України. Робота соціальних педагогів має бути направлена на формування у молоді почуття патріотичної приналежності саме до своєї держави. В цьому напрямку увага і підтримка патріотичного виховання дітей та молоді має фундаментальне значення, як фактор запоруки економічного процвітання та єдності України. Соціально-педагогічна наука повинна бути спрямована на реформування, розвиток, поглиблення і вдосконалення процесу патріотичного виховання молодого покоління, бути об’єднавчою ланкою в діяльності різноманітних патріотичних громадських організацій. Почуття патріотизму необхідно базувати не тільки на сучасних героїчних прикладах захисту державності України в умовах російської військової агресії, але й на фундаменті багатовікової боротьби українського народу за свою незалежність, самобутність 3 урахуванням історичних досягнень в галузях науки, культури, мистецтва і спорту.

Розвиток технологій та методів патріотичного виховання дітей та молоді надасть можливість соціальним педагогам постійно підвищувати професійний рівень своєї роботи в залежності від нових потреб суспільства. 
Перспективами досліджень в напрямку патріотичного виховання дітей та молоді можуть бути результати взаємодії соціальних служб 3 патріотичними громадськими, волонтерськими організаціями та православними релігійними громадами. Їх багатопланова патріотична діяльність може стати фундаментом для формування нових сучасних засобів впливу на патріотичну свідомість учнівської молоді, інструментів подолання почугтя байдужості до проблем в державі, низького духовного та культурного рівня, відсутності чітких світоглядних засад. Для цього необхідно створювати в соціально-педагогічній діяльності чіткі ціннісні орієнтири для молодого покоління.

\section{Література}

Бех, І. Д., Чорна, К. І. (2014). Програма українського патріотичного виховання дітей та учнівської молоді. Київ, 29 с.

Вайнола, Р. Х. (2012). Технологія соціальна. Енциклопедія для фахівців соціальної сфери / за заг.ред. І.Д.Звєрєвої. Київ ; Сімферополь : Універсум, 510-511.

Заверико, Н. В. (2012). Технологія соціальної / соціально-педагогічної роботи. Енциклопедія для фахівців соціальної сфери / за заг. ред. І. Д. Звєрєвої. Київ ; Сімферополь : Універсум, 513-514.

Капська, А.Й. (2015). Технології соціально-педагогічної роботи : Навчальний посібник / А. Капська. К.: Слово, 328 с.

Ковальчук, І. В. (2016). Технології соціальної роботи з формування патріотизму дітей / I. В. Ковальчук/Збірник наукових праць Кам'янець-Подільського національного університету імені Івана Огієнка. Серія : Соціально-педагогічна. Вип. 26, 109-117. 


\title{
THE ROLE OF SOCIAL PEDAGOGES IN PATRIOTIC EDUCATION OF CHILDREN AND YOUNG PEOPLE
}

\author{
Yaroslav Spivak, Ph.D., Associate professor, Doctoral Student of the State Higher \\ Educational Institution «Donbas State Pedagogical University», \\ Donetsk region, Slavyansk, Ukraine, \\ Yaroslavspivak777@gmail.com
}

\begin{abstract}
The actual problem of patriotic upbringing of children and youth, the formation of their national consciousness and civic attitudes discussed in the article. The special role of patriotic education in the formation of a young person as a citizen is highlighted. The patriotic upbringing in the context of modern socio-pedagogical realities is considered. The crisis situation of the socio-political conditions of the young generation's existence is emphasized. In modern conditions, the growing role of social pedagogues in the patriotic education of children and youth is noted. The main tasks of social work in this direction, requirements to professional qualities of social pedagogues are defined. The main technologies of social work that can be applied in forming patriotism of children and youth are characterized. The content of social work technologies with families who have suffered from military aggression is revealed. In the article, social work is considered as a significant means of forming patriotism not only children, the younger generation, but also their families. The expediency of development of optimal directions of social and pedagogical activity in patriotic education of children and youth of Ukraine is substantiated. In order to organize the patriotic education of students in educational institutions, recommendations were given to social educators. Summarized the importance of social pedagogue function in cooperation with all participants in the process of patriotic education of children and younger generation. The necessity of state support in this direction is emphasized not only educational establishments, social institutions, social institutions, medical, legal institutions, public organizations, but also necessarily all those who wish to this process. The further research will be focused on the multidimensional activities of social educators for the formation of new young patriots generations to defend the future independence and prosperity of Ukraine.
\end{abstract}

Key words: patriotic education of children and youth; patriotism; the role of a social teacher; social work; social work technologies.

\section{References}

Bech, I. D., Chorna, K. I. (2014). The program of Ukrainian patriotic education of children and pupils. Kiev, 29. [In Ukrainian].

Vainola, R. K. (2012). Social technology. Encyclopedia for specialists in social field / gen. ed. by I. D. Zviereva. Kyiv ; Simferopol : Universum, 510-511. [In Ukrainian].

Zaveriko, N. V. (2012). Technology for social / social-pedagogical work. Encyclopedia for specialists in social field / gen. ed. by I. D. Zviereva. Kyiv ; Simferopol : Universum, 513-514. [In Ukrainian].

Kapska, A. Y. (2015). Technologies of social and pedagogical work: Textbook / A. Kapska. K .: Word, 328. [In Ukrainian].

Kovalchuk, I. V. (2016). Technologies of social work on the formation of children's patriotism / I. V. Kovalchuk // Collection of scientific works of Kamenets-Podolsky National University named after Ivan Ogienko. Series: Socio-pedagogical. Whip 26, 109117. [In Ukrainian]. 
